Sri Lanka J. Aquat. Sci. 22(1) (2017): 39-44

\title{
Utilization of minor cyprinids (Dawkinsia singhala and Puntius chola) from reservoirs as protein sources for feeds of juvenile koi carp (Cyprinus carpio)
}

\author{
Rochana Weerasingha $^{1 *}$, W.G.C. Umesha Soorasena ${ }^{2 \dagger}$, and D. Ananda Athukorala ${ }^{1}$ \\ ${ }^{1}$ Inland Aquatic Resources and Aquaculture Division, National Aquatic Resources Research and \\ Development Agency, Crow Island, Colombo15, Sri Lanka. \\ ${ }^{2}$ Department of Animal Science, Faculty of Animal Science and Export Agriculture, Uva Wellassa \\ University, Badulla, Sri Lanka.
}

$\dagger$ Present address: Jacobi Carbons Lanka (Pvt) Ltd, " G" Estate, Wathugahamulla, Nattandiya, Sri Lanka

* Corresponding author (rochanaweerasingha@ gmail.com)

\begin{abstract}
Six-weeks of feeding trial was conducted to evaluate the effect of diets formulated using fish meal made from minor cyprinids (Dawkinsia singhala (DS) and Puntius chola (PC)) on the growth of koi carp (Cyprinus carpio) juveniles. Two isonitrogenous (crude protein $-35 \%$ ) experimental diets with average lipid level (dry matter) of $8.96 \pm 0.41 \%$ (mean \pm SD) were prepared containing 30.5\% DS: 9\% fish meal (FM) $\left(\mathrm{T}_{1}\right) ; 33 \%$ PC: $8 \% \mathrm{FM}\left(\mathrm{T}_{2}\right)$. Prima ${ }^{\circledR}$ tropical fish feed was used as the control $\left(\mathrm{T}_{3}\right)$. Each treatment was followed by three replicates and nine cement tanks of $1.5 \mathrm{~m} \times 1.2 \mathrm{~m}$ in size were used to conduct the study. Hundred juvenile koi fish with an average weight of $0.58 \pm 0.03 \mathrm{~g}$ (mean $\pm \mathrm{SD}$ ) were randomly allocated for each tank. At the end of feeding trial, no significant differences were found in weight gain, specific growth rate, feed conversion ratio, protein efficiency ratio and survival rate among fish fed 3 diets $(P>0.05)$. The results indicated that two minor cyprinid species selected in the present study could be utilized as a protein supplement in juvenile koi carp feeds to replace high cost fish meals.
\end{abstract}

Keywords: carp feeds, koi carps, minor cyprinids, ornamental fish, small indigenous species

\section{INTRODUCTION}

Koi carp (Cyprinus carpio) is a popular ornamental fish variety, and in Sri Lanka, import and breeding of koi carps are mostly for local hobbyists. Ornamental fish culture practices depend on the formulated feeds, and feed cost attributes a major cost component related to this industry. As such, preparation of a suitable feed type for koi carps using cheap, locally available ingredients would be a promising means for the development this important ornamental fish farming sector in Sri Lanka. For fish feed formulation, one of the expensive ingredients that is generally used as the protein source is good quality fish meal (Hasan and Halwart 2009; Tacon and Metian 2009; Hasan 2012).

As in many lacustrine water bodies in Asia (De Silva et al. 1991), the capture fishery in Sri Lanka is almost entirely dependent on exotic cichlid species, most notably Oreochromis mossambicus and $O$. niloticus (Amarasinghe and De Silva 1996; Amarasinghe 1998; Amarasinghe and Weerakoon 2009). However, it has been reported that minor cyprinid species such as Amblypharyngodon melettinus, Dawkinsia singhala and Puntius chola, which are hitherto unexploited in commercial scale due to low consumer preference, are abundant in the reservoir fish communities (Amarasinghe 1985, 1990; De Silva and Sirisena 1987; Schiemer et al. 2001). The fishery potential of this untapped fishery resource in reservoirs was found to be very high and through commercial scale exploitation, they may support a supplementary annual fish harvest of about 22,000 tonnes (Amarasinghe et al. 2009, 2016).

Amarasinghe (1990) stated that this unexploited fishery resource can be utilized in the 
form of dried fish or can be used for making fish meal for aquaculture. Amarasinghe et al. (2002) have shown that fish feeds prepared using dried fish powder of minor cyprinids could be used for feeding Indian major carp reared in floating net cages. In the present study, an attempt was made to evaluate the effect of a feed formulated using fish meal made from two species of minor cyprinids, D. singhala and P. chola, on the growth of koi carp juveniles.

\section{MATERIALS AND METHODS}

\section{Experimental diets and design}

Two isonitrogenous (crude protein- 35\%) feeds with average lipid levels (dry matter) of $8.96 \pm 0.41 \%$ (means $\pm \mathrm{SD}$ ) were prepared substituting commercially available fish meal by dried $D$. singhala fish powder $\left(\mathrm{T}_{1}\right)$ and dried $P$. chola fish powder $\left(\mathrm{T}_{2}\right)$ in the feed laboratory of Inland Aquatic Resources and Aquaculture Division at National Aquatic Resources Research and Development Agency (NARA) (Table 1). Commercial fish feed (Prima ${ }^{\circledR}$ Tropical Fish Feed; $\mathrm{T}_{3}$ ) was used as a control. The three types of feeds were randomly assigned to three replicates groups.
Feed ingredients (Table 1) were purchased from local market. Minor cyprinids were caught from Chandrika wewa, an irrigation reservoir, using $32 \mathrm{~mm}$ stretched mesh gill nets with the help of fishers in the reservoir. Fish were dried using a solar dryer ("SAVIRU", Sri Lanka) and grounded by a hammer mill (model of Single-phase cap acitorstart motor, China). All ingredients were then sieved through a 0.5 $\mathrm{mm}$ mesh separately. Analysis of proximate composition (moisture, ash, fat and crude protein) of all ingredients and fish powder of two minor cyprinid species separately was carried out following AOAC (1995) methods prior to making feed formula. All ingredients were then weighed and mixed them together for 20-30 minutes using a "CHERRY" blender (Sheang Lien Industrial Co, Ltd, Thaiwan), and meanwhile fish oil was added to the mixture. Tap water was then added until a dough was formed which was passed through a pellet machine to make $2 \mathrm{~mm}$ pellet. Pellets were oven dried at $50^{\circ} \mathrm{C}$ for overnight and crushed and sieved through a sieve set (mesh sizes $0.5 \mathrm{~mm}$ and $2 \mathrm{~mm}$ ). Then pellets were packed and stored at $-20^{\circ} \mathrm{C}$ until they were used for feeding trial.

Table 1 Feed formulae of formulated diets (\% of Dry Matter (DM) basis)

\begin{tabular}{lccc}
\hline \multirow{2}{*}{ Feed ingredients } & \multicolumn{3}{c}{ Diets } \\
\cline { 2 - 4 } & $\mathrm{T}_{1}$ & $\mathrm{~T}_{2}$ & $\mathrm{~T}_{3}$ \\
\hline Fish meal & 9 & 8 & \\
Dried D.singhala & 30.5 & 0 & \\
Dried P.chola & 0 & 33 & \\
Soya bean meal & 24 & 24 & \\
Meat meal & 1 & 1 & \\
Coconut oil meal & 5 & 5 & \\
Rice bran & 6.5 & 6.5 & \\
Wheat flour & 20.7 & 18.3 & \\
Maize meal & 1 & 1 & \\
Fish oil & 0.8 & 1.7 & \\
Vitamin mineral & & & \\
pre-mixture & 1.5 & 1.5 & \\
Proximate composition & $\%$ of DM basis $)$ & & \\
Moisture & $7.28 \pm 0.13$ & $8.23 \pm 0.17$ & \\
Ash & $14.52 \pm 0.09$ & $15.11 \pm 0.20$ & \\
Lipid & $8.67 \pm 0.28$ & $9.25 \pm 0.14$ & \\
Protein & $34.51 \pm 0.12$ & $34.73 \pm 0.16$ & $39.32 \pm 0.75$ \\
& & & \\
\hline
\end{tabular}

\section{Experimental fish and feeding trial}

Koi carp juvenile fish were procured from carp breeding centre, Ginigathena, Sri Lanka. Feeding trials were conducted in an outdoor, freshwater tank system for 42 days at NARA, Sri Lanka.

Sri Lanka J. Aquat. Sci. 22(1) (2017): 39-44 


\section{R. Weerasinghe et al.}

Nine hundred juvenile koi carps with initial average weight of $0.58 \pm 0.03 \mathrm{~g}$ (mean $\pm \mathrm{SD}$ ) were randomly allocated into nine cement tanks of $1.5 \mathrm{~m}$ $\times 1.2 \mathrm{~m}$ size. Experimental fish were acclimatized to cement tanks and feeds for ten days while providing the commercial feed and formulated feeds together. Initially fish were fed with $10 \%$ of biomass and then $7 \%, 6 \%, 5 \%$ and $4 \%$ in sequence for each tank. Feeding was done three times per day (09:00, 12:00 and 15:00). Feeding rate was adjusted according to the body weight. Water temperature, $\mathrm{pH}$ and dissolved oxygen were maintained at $26.2 \pm 0.1^{\circ} \mathrm{C}, 7.9 \pm 0.76$ $\mathrm{pH}$ and $4.5 \pm 0.5 \mathrm{mg} \mathrm{L}^{-1}$ (mean $\pm \mathrm{SD}$ ), respectively. One-third of water exchange was done twice a week while bottom siphoning was carried out daily. Fish mortalities and behaviour were recorded at every feeding time.

\section{Sample analysis}

Weight of three samples consisting 20 fish per each sample was taken from each tank separately after every 2 weeks. Fish were starved for 12 hrs before weighing. Percent weight gain $[\mathrm{WG}=$ (final weight Initial weight $\times 100 /$ Initial weight], specific growth rate $[S G R=$ (ln final weight $-\ln$ initial weight $) /$ days], feed conversion ratio $[$ FCR $=$ feed intake $(\mathrm{g}) \times 100$ /weight gain (wet) $(\mathrm{g})]$, protein efficiency ratio [PER = weight gain (wet) $(\mathrm{g}) /$ protein intake $(\mathrm{g})]$ and survival rate $[S R==$ total fish stocked $\times 100 /$ number of fish survived at the end] were calculated.
Proximate composition of fish and experimental diets was determined by standard methods of AOAC (2000). Samples of diets and experimental fish were dried at $105^{\circ} \mathrm{C}$ until a constant weight to determine the moisture content in sequence. Crude protein content was determined by the Kjeldhal method following main steps of digestion, distillation and titration. Crude fat was quantified by chloroform methanol method and ash content was determined by incineration at $550^{\circ} \mathrm{C}$.

\section{Statistical Analysis}

Calculated WG, SGR, FCR, PER, and SR data were analyzed by One -way Analysis of Variance (ANOVA). Least significant difference (LSD) and Tukey's HSD were used to find the treatment effect at $\mathrm{P}<0.05$ level of significance using Statistical Analysis System (SAS Institute Inc. 2000).

\section{RESULTS}

\section{Proximate analysis}

Proximate composition of $D$. singhala and $P$. chola is shown in Table 2. There were significant differences in moisture, ash and fat compositions of two species $(P<0.05)$. However there was no significant difference in protein composition of two species $(P>0.05$; Table 2). In whole body proximate analysis of koi carp, there were no significant differences in moisture, ash, fat and protein contents among those of fish fed $\mathrm{T}_{1}, \mathrm{~T}_{2}$ and $\mathrm{T}_{3}(P>0.05$; Table 3$)$.

\section{Proximate composition analysis}

Table 2 Whole body proximate compositions of $P$. singhala and $P$. chola (\% dry matter basis)

\begin{tabular}{lllll}
\hline & Moisture* & Ash & Lipid & Protein \\
\hline D. singhala & $9.17 \pm 0.18^{\mathrm{a}}$ & $17.21 \pm 0.21^{\mathrm{a}}$ & $18.21 \pm 0.21^{\mathrm{a}}$ & $50.62 \pm 0.44^{\mathrm{a}}$ \\
P. chola & $7.51 \pm 0.52^{\mathrm{b}}$ & $15.77 \pm 0.43^{\mathrm{b}}$ & $14.27 \pm 0.19^{\mathrm{b}}$ & $49.28 \pm 1.43^{\mathrm{a}}$ \\
\hline
\end{tabular}

* Note: Moisture content was determined for dried fish powder.

Values (mean \pm standard deviation of data for triplicate groups) with the different superscripts in the same column are significantly different $(P<0.05)$. 
Table 3 Whole body proximate compositions of koi carp (\% of dry matter basis) $(P<0.05)$ at the beginning (initial) and end (final) of the feeding trials

\begin{tabular}{ccccc}
\hline & Moisture $^{*}$ & Ash & Lipid & Protein \\
\hline Initial & $9.67 \pm 0.14^{\mathrm{a}}$ & $11.65 \pm 0.46$ & $11.6 \pm 0.21^{\mathrm{a}}$ & $58.29 \pm 0.12$ \\
Final & & & & \\
$\mathrm{T}_{1}$ & $4.31 \pm 0.52^{\mathrm{b}}$ & $11.93 \pm 0.68$ & $29.43 \pm 6.05^{\mathrm{b}}$ & $53.95 \pm 3.91$ \\
$\mathrm{~T}_{2}$ & $4.23 \pm 0.76^{\mathrm{b}}$ & $12.05 \pm 0.75$ & $34.65 \pm 10.33^{\mathrm{b}}$ & $52.35 \pm 2.88$ \\
$\mathrm{~T}_{3}$ & $4.02 \pm 1.03^{\mathrm{b}}$ & $11.6 \pm 0.18$ & $24.02 \pm 1.11^{\mathrm{b}}$ & $57.53 \pm 1.21$
\end{tabular}

* Moisture content was determined for dried fish powder

Values (mean \pm standard deviation of data for triplicate groups) with the different superscripts in the same column are significantly different $(\mathrm{P}<0.05)$.

\section{Growth performance}

During 42 days of feeding trial, all diets were well accepted by fish. There was no significant difference in survival rate among three treatments $(P>0.05)$.
Growth performance values (WG, SGR, FCR and PER; Table 4) had no significant difference among fish fed with three different diets $(P>0.05)$.

Table 4 Growth performances of juvenile koi carps fed three diets for 6 weeks. IW - Initial weight ( $\left.\mathrm{g} \mathrm{fish}^{-1}\right)$; FW - Final weight $\left(\mathrm{g} \mathrm{fish}^{-1}\right)$; WG - Weight gain (\%); SGR - Specific Growth Rate (\% day $\left.{ }^{-1}\right)$; FCR: Feed Conversion Ratio (\%); PER: Protein Efficiency Ratio; SR - survival rate (\%); Pooled SEM= Pooled Standard Error of Mean

\begin{tabular}{ccccc}
\hline & \multicolumn{3}{c}{ Diets } & Pooled \\
\cline { 2 - 4 } & $\mathrm{T}_{1}$ & $\mathrm{~T}_{2}$ & $\mathrm{~T}_{3}$ & SEM \\
\hline IW & 0.57 & 0.57 & 0.59 & 0.01 \\
FW & 1.23 & 1.26 & 1.23 & 0.03 \\
WG & 118.15 & 120.24 & 108.92 & 6.20 \\
SGR & 1.85 & 1.87 & 1.75 & 0.07 \\
FCR & 3.02 & 3.09 & 3.11 & 0.13 \\
PER & 0.97 & 0.96 & 0.82 & 0.05 \\
SR & 99.67 & 99 & 99.67 & 0.24 \\
\hline
\end{tabular}

\section{DISCUSSION}

D. singhala had significantly high amount of moisture, ash and fat content than $P$. chola. Protein contents of $D$. singhala and $P$. chola varied in a very narrow range. According to Mazumder et al. (2008), protein contents (in wet weight basis) of Amblypharyngodon mola, Gudusia chapra, Puntius chola, Chanda nama, Pseudeutropius atherinoides and Ailia coila were $18.46,15.23,14.08,18.26,15.84$ and $16.99 \%$ respectively. The percent fat contents recorded for the same species were $4.10,5.41,3.05,1.53,2.24$ and $3.53 \%$ respectively. Also, moisture and ash contents (in wet weight basis) of P. chola were 74.43 and 1.19 $\%$ respectively (Mazumder et al. 2008).
Replacing fish meal by minor cyprinid powder in the study was not showing any significant difference in resulted WG, SGR, FCR, PER and SR after 42 days of feeding trial. WG and SGR decreased in fish fed $\mathrm{T}_{2}, \mathrm{~T}_{1}$ and $\mathrm{T}_{3}$ diets in sequence. According to Emre et al. (2003), in a study with mirror carp fingerlings by replacing fish meal with poultry byproduct meal in practical diets, average weight gain of carp fingerlings fed the control $(0 \%$ inclusion of poultry by product meal with fish meal) was significantly higher compared to those fed with diets of poultry byproduct meal. The same study showed that when the inclusion level of poultry byproduct meal replacing fish meal was increased it has decreased the WG. According to $\mathrm{Hu}$ et al. (2008), replacement of fish meal by rendered animal protein ingredients with lysine and methionine supplementation in practical diets for gibel carp,

Sri Lanka J. Aquat. Sci. 22(1) (2017): 39-44 
Carassius auratus gibelio, the optimal replacement level of fish meal by the combination of poultry byproduct meal, meat and bone meal with lysine and methionine supplementation was $66.7 \%$ of protein.

Although FE and PER decreased in fish fed $\mathrm{T}_{2}, \mathrm{~T}_{1}$ and $\mathrm{T}_{3}$ diets and also fish fed both with $\mathrm{T}_{1}$ and $\mathrm{T}_{2}$ diets expressed high growth performances over the commercial diet $\left(\mathrm{T}_{3}\right)$. Formulated diets were prepared to meet optimum dietary requirements of koi carp. Their daily protein requirement is about $1 \mathrm{~g} \mathrm{~kg}^{-1}$ body weight for maintenance and $12 \mathrm{~g} \mathrm{~kg}^{-1}$ body weight for maximum protein retention. Generally, it is known that the optimal crude protein levels in the fish diets are between 30 to 38\% (FAO 2013), and the protein level could be kept at 30\%-35\% if the diets contain enough digestible energy (Watanabe 1982). In the present study, reduction of protein content of koi carps fed with two formulated diets was evident when compared to those fed with commercial diet (Table 3), which perhaps indicated that commercial feed helped fish to maintain protein content in the body almost equal to initial level.

Minor cyprinids like D. singhala and P. chola may comprise essential amino acids, essential fatty acids and minerals which are required for growth of koi carp. Mazumder et al. (2008) stated that small indigenous fishes like $P$. chola, A. mola, etc are of high nutritional value due to proteins and vitamins which are not commonly available in sufficient quantities in other food stuffs. As the fishery potential for minor cyprinids in major and medium perennial reservoirs of Sri Lanka is estimated to be about 250 kg.ha ${ }^{-1}$ year $^{-1}$ which is about 22,000 tonnes of fish (Amarasinghe et al. 2009), this resource can be used as a source of fish meal in formulating fish feeds for koi carps. Further research is needed to analyze amino acid compositions, fatty acids profile, mineral profile of minor cyprinids and; the effects of essential amino acids, essential fatty acids and minerals in minor cyprinid carcasses on growth of koi carp.

\section{Acknowledgements}

Authors acknowledge support of National Aquaculture Development Authority and officials of carp breeding centre, Ginigathena and facilities provided by NARA to carry out this study. Fishers of Chandrika wewa helped us to obtain fish samples from the reservoir. Two anonymous referees gave constructive comments to improve the manuscript.

\section{REFERENCES}

Amarasinghe U.S. 1985. Studies on the exploitation of minor cyprinids in Parakrama Samudra, a man-made lake in Sri Lanka, using gill nets. Journal of National Aquatic Resource Agency 32: 11-23.

Amarasinghe U.S. 1990. Minor cyprinid resources in a man-made lake in Sri Lanka: a potential supplementary source of income for fishermen. Fisheries Research 9: 81-89. doi:10.1016/01657836(90)90043-U

Amarasinghe U.S. 1998. Reservoir fisheries management in Sri Lanka: Achievements, mistakes and lessons for future. International Review of Hydrobiology 83 (Special Issue): 523-530.

Amarasinghe U.S. and S.S. De Silva 1996. Impact of Oreochromis mossambicus $X \quad O$. niloticus (Pisces: Cichlidae) hybridization on population reproductive potential and long-term influence on a reservoir fishery. Fisheries Management and Ecology 3: 239-249. doi:_10.1111/j.13652400.1996.tb00151.x

Amarasinghe U.S., P.A.D. Ajith Kumara and M.H.S. Ariyaratne 2002. Role of non-exploited fishery resources in Sri Lankan reservoirs as a source of food for cage aquaculture. 332-343 pp. In: I.G. Cowx (ed.) Management and Ecology of Lake and Reservoir Fisheries. Fishing News Books, Blackwell Science, Oxford.

Amarasinghe U.S., Ajith Kumara, P.A.D. and S.S De Silva 2016. A rationale for introducing a subsidiary fishery in tropical reservoirs and lakes to augment inland fish production: case study from Sri Lanka supplemented with evidence from elsewhere. Food Security 8: 769-781. doi: 10.1007/s12571-016-0596-4

Amarasinghe U.S. and D.E.M. Weerakoon 2009. Present status and future strategies for the management of reservoir fisheries in Sri Lanka. 69-98 pp. In: De Silva, S.S. and U.S. Amarasinghe (eds.), Status of reservoir fisheries in five Asian countries. NACA Monograph No. 2. Network of Aquaculture Centres in Asia-Pacific, Bangkok, Thailand. 116p.

Amarasinghe U.S., D.E.M. Weerakoon and D.A. Athukorala 2009. Emerging boots in Sri Lanka reservoir fish production: a case of 
adoption of past research findings. Aquaculture Asia 14: 26-28.

AOAC 1995. Official Methods for Analysis, $14^{\text {th }}$ Edition. Association of Official Analytical Chemists, Arlington, VA., USA.

De Silva S.S. and H.K.G. Sirisena 1987. New fish resources of reservoirs in Sri Lanka. Feasibility of introduction of a subsidiary gillnet fishery for minor cyprinids. Fisheries Research 6: 17-34. doi: 10.1016/01657836(87)90004-X

De Silva S.S., J. Moreau, U.S. Amarasinghe, T. Chookajorn and R.D. Guerrero 1991. A comparative assessment of the fisheries in lacustrine inland waters in three Asian countries based on catch and effort data. Fisheries Research 11: 177-189. doi: 10.1016/01657836(91)90107-Q

Emre Y., H. Sevgili and I. Diler 2003. Replacing fish meal with poultry by-product meal in practical diets for mirror carp (Cyprinus carpio) fingerlings. Turkish Journal of Fisheries and Aquatic Sciences 3: 81-85.

FAO 2013. Aquaculture Feed and Fertilizer Resources Information System: Common carp Cyprinus carpio.

http://www.fao.org/fishery/affris/species-

profiles/common-carp/common-carp-

home/en/ (Accessed 04 September 2013).

Hasan M.R. 2012. Transition from low-value fish to compound feeds in marine cage farming in Asia. FAO Fisheries and Aquaculture Technical Paper No. 573. Food and Agriculture Organization, Rome. 198 p.

Hasan M.R. and M. Halwart 2009. Fish as feed inputs for aquaculture: practices, sustainability and implications. FAO Fisheries and Aquaculture Technical Paper No. 518. Food and Agriculture Organization, Rome. 407 p.

Hu M., Y. Wang, Q. Wang, M. Zhao, B. Xiong, X. Qian, Y. Zhao and Z. Luo 2008. Replacement of fish meal by rendered animal protein ingredients with lysine and methionine supplementation to practical diets for gibel carp, Carassius auratus gibelio. Aquaculture 275: $260-265$.

doi: 10.1016/j.aquaculture.2008.01.005

Mazumder M.S.A., M.M. Rahman, A.T.A. Ahmed, M. Begum and M.A. Hossain 2008. Proximate composition of some small indigenous fish species (SIS) in Bangladesh. International Journal of Sustainable Crop Production 3: 1823.

Schiemer F., U.S. Amarasinghe, J. Frouzova, B. Sricharoendham and E.I.L. Silva 2001. Ecosystem structure and dynamics - a management basis for Asian reservoirs and lakes. 215-226 pp. In: S.S. De Silva (ed.), Reservoir and Culture-based Fisheries: Biology and Management ACIAR, Canberra, Australia.

Tacon A.G.J. and M. Metian 2009. Fishing for feed or fishing for food: increasing global competition for small pelagic forage fish. Ambio: A Journal of the Human Environment 38(6): 294-302. doi: 10.1579/08-A-574.1

Watanabe T. 1982. Lipid nutrition in fish. Comparative Biochemistry and Physiology 73: 3-15. doi:10.1016/0305-0491(82)90196-1 